\title{
THE PERPETUAL OBJECT OF REGULATION: PRIVACY AS PACIFICATION
}

\author{
AARON HENRY \\ Carleton University, Canada ${ }^{1}$
}

\begin{abstract}
This article theorizes the relationship of privacy to capital and projects of security and, in doing so, situates privacy in context to pacification. In particular, the article provides an interrogation of the contradictory structuring of privacy as both an object threatened by security and the role of privacy as a means to resist or limit projects of security. Through an analysis of Thomas Hobbes' writings, this contradictory dual-deployment of privacy is unseated to reveal that far from challenging security, privacy has historically been presupposed and structured by security projects. Moreover, by acclimatizing us to our existence as atomized individuals, alienated from our collective social power, privacy in fact pacifies us. This process is explored through an examination of the Passenger Flight List agreement (PNR) between the United States and EU member states. The article concludes with a brief discussion of the implications of our reliance on privacy has for challenging the logics of security and pacification, especially with the emergent technology of Drones.
\end{abstract}

\section{Keywords}

Privacy, Capital, Pacification, Passenger Flight Lists, Anti-Security

There is a conviction today that privacy is in a state of irretrievable crisis. In addition to the collection and sale of day-to-day personal activity by telecommunications services and social networking sites, programmes of surveillance and registration have allegedly eroded what were previously understood as the firm borders between public and private spheres of relations. That this has happened or is in the process of materializing

\footnotetext{
${ }^{1}$ Aaron Henry is a PhD candidate at Carleton University reading Sociology and Political Economy. Acknowledgement: I would like to thank George Rigakos for his support and encouragement in my studies into anti-security. I would also like to thank Mark Neocleous for his help in editing this paper into a more readable version. Finally, a huge intellectual debt is owed to Justin Paulson whose guidance in reading Marx informs much of what follows. This paper was completed with support from the Social Sciences and Humanities Research Council. Any errors are the sole products of my labour.
} 
has taken on the weight and opacity of a social fact. Yet, while privacy is said to be in a state of crisis, the 'right to privacy' is often trumpeted by liberals as the counterweight to balance the intrusion of state projects into the lives of individuals. Indeed, this appears to be the general sentiment that rests behind initiatives like the 'Orwell Award' given to companies that have violated privacy, or the American Civil Liberties Union recent mobilization against Drones as a privacy concern. Thus, privacy is presented as means to make intrusions into the life of the individual proportional to the objectives of security projects, and in some instances security projects are legitimized for the forms of privacy they safeguard (Cavoukian, 1999, 13). To this end, privacy is subject to a rather peculiar positioning as both a relation threatened by security and as a regulative principle capable of ensuring the 'acceptable' limits of security projects.

What I want to demonstrate in this paper is that the relation of privacy to security as both an object threatened by security and as a means of regulating security projects is the product of a longstanding relation between privacy, security and capital. This relation is expressed in two ways. First, while privacy has been invoked as a means to resist projects of security, I argue that privacy is in fact deployed as a means to structure the fields of relations through which security interventions are made. ${ }^{2}$ In this sense, when the power of state or capital intervenes upon the individual, privacy emerges as a concept. Privacy, a retroactive concept, exists as a means to assuage individuals that the duration and scope of security projects will be 'reasonable or proportional'; thus, security presupposes and delimits privacy. Second, in the course of defending the individual's freedom and autonomy over their inner world, privacy reinforces private property and private life, the very relations projects of security safeguard. Thus, privacy acclimatizes us to a mode of existence where we are alienated from our collective social power, and so we confront relations of domination and exploitation as private individuals. This commodification of our selves is, I suggest, part of the condition of pacification.

First, I attempt to theorize how security and its relation to capital render it not only generative of privacy but structure its perimeters. I demonstrate the formation of this relationship between security and privacy through a critical reading of Thomas Hobbes' Leviathan. Second, I offer a contemporary example of this relation between privacy and security through an analysis of the Passenger Name Record (PNR) agreement between the United States and the EU. Finally, I conclude by reviewing how privacy as desirable form of existence constitutes a form of pacification insofar as it not only fails to challenge capital but has further entrenched the logics of security into social life.

\footnotetext{
${ }^{2}$ In this sense, I am taking a different stance from scholars like Steve Nock, who have argued that demands for privacy have engendered more complex and extensive projects of surveillance (see Nock 1993).
} 


\section{Capital, Security, Privacy}

The relation between capital and the formation of the private sphere/privacy is hardly a novel study. In the Grundrisse, Marx lays out the relationship between the different historical formations of property-relations and corresponding forms of political association to demonstrate that it is with the advent of private-property that the totality of social life is split into the duality of private and public selves (Marx, 1973, 486; Marx, 1975, 222; see Neocleous, 2002,). In many respects, Jurgen Habermas' seminal work The Structural Transformation of the Public Sphere reworks Marx's insight. Habermas locates the formation of private life and, therein, the bourgeois public sphere in the "social precondition... [of] a market that, tending to be liberalized made the affairs in the sphere of social reproduction as much as possible a matter of private people" $(1991,74)$. To this end, the duality of private and public life is the product of a capitalist market with a form of state authority that exists to guarantee this private life with the liberal political virtue of "freedom": freedom of movement, of trade, and of conscience. While Habermas's study effectively links capitalist development to the formation of private life, the relation of private life to security projects remains underdeveloped. In fact, taking private life as the space where liberal freedoms are articulated autonomously through the 'free space' of civil society ignores the logics of security in capitalist society. Thus, it can be argued that adopting Habermas' view leaves us vulnerable to falling back on the contradictory position of privacy as a relation that is both threatened by and regulative of, security. We can perhaps move past this contradictory perception of privacy by trying to think through privacy in relation to security and capitalist production.

What is, then, the relation of security to capital? No doubt any answer to this question will be partial. Nevertheless it is useful to open this question by noting that Marx declared "security the supreme social concept of civil society; the concept of police" $(1975,43)$. To this end, Marx's reasoning behind this appears to be that the concept of security not only ensures egoism but that the only "bond between men is natural necessity, need and private interest, the preservation of their property" $(1975,43)$. If we take a liberal perspective, the matter is settled: security exists to guarantee the supremacy of the individual in their private life so that they may in turn pursue their own private interests; thus, security does not serve capital but private individuals who express themselves in what happens to be capitalist society (see Von Mises 1962, 68). But, to take this position is to overlook Marx's further insight that private life in capitalist society is nothing more than an abstraction (Marx, 1978, 22). Private-life, its mode of articulation and form of existence is nothing more than abstract reflection of real relations between private-property. Thus, security ensures the liberty to buy and sell labour, the freedom of mobility, freedom of conscience. More broadly put, it ensures the "separation of man from man" and does so in the course of solidifying and entrenching the social relations 
that stand behind these freedoms: the relations of private property (Marx, 1978, 46). Not only has this point been well established (see Rigakos, and Hadden 2001; Rigakos 2011; Neocleous 2007) but, further still, as the guarantee of private property first and the freedom of the liberal subject second, security perpetually determines and conditions liberty (Neocleous, 2007) ${ }^{3}$.

Thus security pertains not to the freedoms of the individual as they actually exist actively but in terms of the abstract universal freedoms that are determined by the formation of private-property relations. This point is effectively borne out in the understanding of police in eighteenth century thought. Adam Smith is quite clear that police, as having jurisprudence over public-security, must be deployed as a means to safeguard not only the industry of people but also the conditions of industry itself. In particular, security is necessary to protect "the industry of individuals from the rapacity of their neighbours" as individuals who "find themselves every moment in danger of being robbed of all they posses [have] not motive to be industrious" (2009, [1763, 157). Moreover, security should be utilized to establish commerce and manufacturing, as the independence these [activities] provide is the "best police in preventing crimes" (2009, [1763], 152). In short, security or police for Smith are not rooted so much in safeguarding the individual but in safeguarding industry and commerce themselves; in other words, maintaining above all else the social relations of private property as these social relations produce opulence and thus order. Patrick Colquhoun is even less abashed about the relation of security to capital as he simply states in his Treatise on the Police of the Metropolis that the function of police as the "prevention and detection of crimes" but the "internal regulations for the well ordering and comfort of civil society" (Colquhoun, 1800 [1795], 244); thus, as others have noted, this well-ordering and comfort of civil society pertain above all else to the continuity of capitalist social relations (Rigakos 2011; Neocleous 2000). All this has been established. What remains elusive here though is how this relation between security and capital relates to private life. In this sense, why is it that far from confronting security, private life and privacy are in fact generated within security? The writings of Hobbes are useful in sketching out the emergence of this conditioning relation between security and privacy.

Much of Leviathan is devoted to the 'Mortal Sovereign' as a necessary form of political covenant. The necessity of the covenant, arguably, stems from three positions. Foremost, each individual, by the law of nature, has the liberty "to use his own as he will himself for the preservation of this nature; that is to say, of his own life" and, consequently, "has a right to every thing; even to one another's body" (Hobbes, 1968, [1651], 189-190). Second, while each individual is not only by nature free to use their own

\footnotetext{
${ }^{3}$ The literature on alienation and its various social forms in capitalist society has a vast literature, see for instance, B. Ollman's classic 1971 work: "Alienation: Marx's conception of man in capitalist society" or István Mészáros, 1970, "Marx’s Theory of Alienation”.
} 
powers as they see fit, nature itself has accorded each individual with the same, or roughly the same, material powers and needs (Macpherson, 1973, 226). Third, and perhaps more importantly, in the course of having equal powers and equal rights to use these powers each individual seeks out society so they "may receive some honour or profit from it" and, moreover that each will come into frequent and potentially violence conflict as they "[have] the appetite to the same thing". Taken together, each individual has a right to anything and relatively equal powers to obtain it; and thus, everyone has a claim to everything. For "if there be no power erected or not great enough for our security; every man will and may lawfully rely on his own strength and art, for caution against all other men" (Hobbes, 1968, [1651], 223); thus, each individual's right to life, liberty, and profit, amount to nothing (Macpherson, 1973, 227). The only solution is the formation of "a common power to keep [all] in awe and to direct [the action of all] to a common benefit" (Hobbes, 1968, [1651], 227). In short, a supreme common power provides the essential security to defend the population against foreign attack and injuries from one another, so that "by their own industrie and by the fruite of the earth" each individual "may be able nourish themselves and live contentedly" (Hobbes, 1968, [1651], 227). In the course of asserting the Mortal Sovereign, Hobbes goes on to make a series of distinctions between liberty, security and publique and private domains.

Chapter XXII of Leviathan is entitled "Of Systems Subject, Politicall, and Private". By systems, Hobbes informs us he means, "any number of men joined in one interest or business". Of these some are absolute and independent (i.e. the Commonwealth) and others are dependent, to the Commonwealth as a person or group persons operating as 'representative' subjects (Hobbes, 1968, [1651], 274; for a discussion Hobbes and authors and actors see Neocleous, 2003, 73). Yet subordinate to these systems are further systems, some "politicall and some private" (Ibid, 274). Private, according to Hobbes, are those "constituted by subjects amongst themselves, or by authorities from a stranger" as no authority from a foreign power in the dominion of another sovereign can be but 'private' (ibid, 275). "Of these private systems some are lawful; some unlawful: lawfull are those which are allowed by the commonwealth" (Ibid, 275). Most of these private systems are irregular. They have no representative (that is, no embodiment of state) and "consist only in the concourse of people...such as the conflux of people to markets or shews or any other harmless end" (ibid, 275). However, if the intention of these irregular private systems "are evil or (if the number [involved is] considerable) unknown, they are unlawful” (ibid, 275).

Hobbes' attempt to partition forms of activity into the categories of 'politicall' and 'private' is noteworthy for several reasons. First, as other scholars have noted, the 'private' as a sphere of activity remained for much of the sixteenth and seventeenth centuries indistinct from the state of being secret (see Abizadeh, 2013, Neocleous, 2002; Sennett, 1974). In this sense, rather than positing private as a state of being concealed, hidden or 
solidary from others (the terms that had been applied to both privacy and secrecy) ${ }^{4}$ Hobbes links the act of being in private to a certain form of association other than that of forms of association posited by the commonwealth. Thus, private life and privacy is foregrounded in Hobbes not as a condition of visibility or boundaries of the home which is for Hobbes the state of secrecy ${ }^{5}$ - but in terms of whether the interest of the individuals involved are 'apart' or separate from organizations and associations that are representations or subordinate elements of the sovereign. What makes this distinction all the more intriguing is that Hobbes arrives at it after outlining the relation of 'particular' (that is, 'private') liberty and the security and liberty of the sovereign.

It is the role of the sovereign to provide security and public defense to all subjects. As such, the subject's liberty exists only in activities and relations that "the sovereign hath permitted" (Hobbes, 1968, [1651], 264). To this end, Hobbes is quite explicit about the forms of activity that are permitted: "the liberty to buy and sell and otherwise contract with one another, to choose their own abode, their own diet, their own trade of life and institute their children as they themselves think fit and the like" (Hobbes, 1968, 264). This liberty, though, is permitted precisely because the liberty (liberty defined by Hobbes as the absence of "external opposition") does not abolish or limit "the sovereign power of life and death" (Hobbes, 1968, 264). Rather, the existence of this form of liberty of 'particular men', the freedom to engage in a private trade or calling, is the product of the security provided by the sovereign, the guarantee of the publique sword and its role in the defense of private men (Hobbes, 1968 386). Furthermore, that there exists inheritance, the propriety of goods or land for private individuals, is not the product of private liberty particular to each man but is, rather a product of the limitation of this liberty by the sovereign's provision of security (Hobbes, 1968 266). There are a few points I want to draw from here.

First, at a cursory glance here it may seem as if I have declared nothing more than that security trumps and presupposes liberty; a feature of capitalist society that Mark Neocleous (2007) has already argued persuasively. However, if Hobbes lays this relation of security to liberty bare, his writings also reveal that it is from this relation that private life itself becomes inscribed as its own distinct sphere of activity. Thus, private life as a sphere of activities that the individual may regulate 'as they see fit' emerges not in opposition to security or sovereign force but, rather, as the product of security. Hobbes demonstrates that it remains the sovereign's prerogative to intervene upon and prohibit certain activities that make up this private association. In particular, private interests are

\footnotetext{
${ }^{4}$ See, Arash Abizadeh 2013 for a discussion on theologists and Calvinists William Perkins and William Strutcher and their use of the words secret and private.

${ }^{5}$ In discussing forms of Worship Hobbes suggests that the first type is "secret" but the second is private and carried out "in the sight of the multitude" (Hobbes, 1968, [1651], 401).
} 
lawful when they are productive and innocuous, but those which harbour evil intents or are simply unknown in motivation are unpermitted and subject to regulation. To this end, private life is presented as being presupposed by security but also and at the same time a perpetual object of surveillance and regulation. Thus, one has the contradictory positioning of private life as the guarantee of the sovereign's security, the point where regulation ends, and private life as a continuum of endless risk to this very security. Taken from the standpoint of private life, privacy appears both as the limitation to security and as the point where this autonomous private life is comprised by sovereign power.

Second, if this is perhaps the relation of privacy to security, what, then, does Hobbes' work tell us about the initial relation between capital, security and privacy? To answer this question in full and with certainty would be remiss given that the milieu Hobbes is writing in is that of early capitalist society, the coming rather than consolidation of bourgeois rule (Macpherson, 1973, 247). Nonetheless, what we can say is that Hobbes's description of human nature as acquisitive and selfish and his imposition of the sovereign as a supreme power presupposes the sphere of accumulation. The Commonwealth is charged with a number of tasks: defense, public worship, security, courts and procreation, but in many respects, much of its purpose is to control what are the innate drives and mechanical processes of human beings. The 'control' of these drives, though, cannot be achieved by stamping them out or blunting them, for they are natural or innate. Hence the task is to atomize each individual's mechanical drive, to instill fear into 'all' so that in the pursuit of profit, glory or status one does not deprive someone else of their own life or property; the sovereign thereby ensures "the absence of opposition" not between the commonwealth and the individual but rather between individuals. In this sense, Hobbes' sovereign produces isolated men and women indifferent to each other as they pursue their own objects, and so ensures the conditions for the sine qua non social bond for capitalist society: "reciprocal independence and indifference" (Marx, 1973, 161). The establishment of market society, the pursuit of profit and accumulation without direct violence, thus requires not only the emergence of security but also the emergence of private life as a mode of mediating the interests of socalled acquisitive individuals.

Last, but related to these first two points, the state of being private, as Hobbes outlines it, is also a means of pacifying individuals to the logics of security. Not only does private life keep individuals apart and disinterested, it also restricts their capacity for rebellion. In particular, Hobbes is quite clear that what is needed to maintain political rule is a 'common' supreme power, to overwhelm individuals into 'obedience'. The power of the sovereign to dictate the rights of life and death leaves individuals too fearful to rebel, but at the same time the very structure and limitations of private life equally restricts the private individual's ability to act in political concert. Private life as a state of existence with neither 'representation' nor the right to 'act' on the behalf of the 
commonwealth, denies individuals the capacity to form political rule. In fact, Hobbes is explicit on the point: it is when individuals gather in private in large numbers for unknown ends or ends that are contrary to the commonwealth that private life must be regulated or suspended. Thus private life, as envisioned by Hobbes, is its own form of pacification. Not only are individuals subjected to market relations but their very form of personal liberty and autonomy is premised on their restriction from forms of political representation or action that challenge sovereign power. The continuity and the effects of this relation between privacy and security can be demonstrated through an examination of the recent agreement on Passenger Name Records (PNR) between the United States and the European Union.

\section{Security and the Perimeters of Privacy: The Passenger Carry Code Agreement}

In 2011 the European Union and the United States ratified The Passenger Carry Code Agreement (PCC). The legislation pertained to the "use and transfer of Passenger Name Records (PNR) to the United States Department of Homeland Security". The document is four chapters in length and outlines the forms of information that airline carries are required to pass along to the EU and the United States government, and the techniques that will be used to protect the privacy of all individuals subject to this legislation. The ratification of the act requires all airlines to implement systems capable of gathering PNRs on nineteen forms of passenger information ranging from the name of the passenger, date of reservation/issue of ticket, personal information such as date of birth, address, gender and in some instances occupation. ${ }^{8}$ I will, briefly, review the specifics of the PCC Agreement.

The preamble of the document reads as follows:

RECOGNIZING, right and responsibility of states to ensure the security of their citizens and protect their borders and mindful of the responsibility of all nations to protect the life and safety of the public including those using

\footnotetext{
${ }^{7}$ The United States had sought such an agreement with a number of countries. A similar arrangement with Canada was ratified in March 2012 with amendments to the Aeronautics Act to by Bill-C42. The Act allows passenger flight information to be sent to the USA and for Canadians to be subject to the restrictions of US no fly lists even if aboard a flight that only enters US airspace on route to another destination.

${ }^{8}$ Full list is as follows: PNR record locator code, date of reservation/issue of ticket, date(s) of intended travel, name (s) on PNR including all available contact information (this includes home addresses if available through the mode of books), all available payment/billing information, travel itinerary for specific PNR, Travel agency/travel agent, code share information, split/divided information, travel status of passenger (including confirmations and check-in status) ticketing information, baggage information, seat information including seat number, general remarks (including special service remarks and special service request (SSR) and information from the advance passenger information system, all historical changes to the PNR listed under points 1-18.
} 
international transport systems... and that information sharing is an essential component in the fight against terrorism and serious transnational crime and that in this context, the processing an use of passenger name records $(\mathrm{PRN})$ is a necessary tool that gives information that cannot be obtained by other means.

Mindful of the EU's commitments pursuant to Article 6 of the Treaty on European Union on respect for fundamental rights, the right to privacy with regard to the processing of personal data as stipulated in Article 16 of the Treaty on the Functioning of the European Union, the principles of proportionality and necessity concerning the right to private and family life, the respect for privacy, and the protection of personal data.

The document then goes on to outline the actual mechanisms in place to facilitate the collection, transfer and sharing of these records. In particular, to ensure the accuracy, security and integrity of the information obtained through PNRs and "to respect the privacy of individuals", PNR data is subject to both sorting and storage procedures (PNR, 2011, 11). All PNR files are to be encrypted, stored in databases secured by "physical intrusion controls" and accessed only by listed authorized individuals. The use of the files will be documented and logged by the Department of Homeland Security. Furthermore in the actual collection of the passenger information of individuals all 'sensitive data' such "as racial or ethnic origin, political opinions, religious or philosophical beliefs, trade union membership, or health/ sex" of the individual will be filtered through automated systems that will censor such information from the DHS (PNR, 2011, 15). In this sense the life of the individual will be filtered through automated systems that will censor such information from the DHS.

This sensitive data will be deleted not later than thirty days after it has been received but in the case of security issues can be retained as required by law enforcement agencies. To this end, while sensitive data should be masked from DHS officials, such sensitive data can be made available to the DHS (PNR, 2011, 15). Furthermore, nonsensitive data can be stored for up to five years and after six months it is to depersonalized by the removal of names, other names on PNR, all available contact information, general remarks and advanced passenger information. Following this active period the document calls for all PNR depersonalized data to be moved to a dormant database for no longer than ten years. The PNR information held on the database can be 'repersonalized' and activated for the purposes of law enforcement operations with identifiable case, threat or risk.

The document concludes by outlining both the safeguards put in place to protect the individual's privacy and a rather meager account of the modes of redress available to individuals who believe their privacy has been violated. These include: the individual's 
right to request copies of the information held about them; to challenge the DHS if they have been "delayed or prohibited from boarding a commercial aircraft because they were wrongly identified as a threat" (PNR, 2011, 21); the right of the individual to have their record withheld from the public; individuals will not face any form of unlawful discrimination in the collection and utilization of their PNR; and, finally, that the individual's request for PNR information is circumscribed by the United States law which may limit the individual's request if such a request conflicts with the necessity to "safeguard privacy-protected, national security, and law enforcement sensitive information" (PNR, 2011, 19). There are three key points that can be made developed here.

First, the PNR agreement reveals that privacy is subservient to the objectives of securing national borders and populations. In this sense, within this document privacy by no means confronts security, challenges it or sets its limits. Rather, those who drafted the agreement have decreed that privacy begins merely where the project of security ceases; thus, what information is excluded, who will access this information, what details are considered sensitive and non-sensitive and the duration of records form the guarantee of privacy. Far from privacy circumscribing security, it is security that circumscribes privacy. Security decrees the activities and relations that can be declared to form the individual's privacy.

Second, it is noteworthy how privacy is constructed and verified within the PNR system. In particular, there is in the document a distinction between the anonymous, non-sensitive depersonalized subject of security and that of the visible individual attributed by trade union membership, religious beliefs and political opinions, sex life and health whose privacy must be 'ensured'. In particular, the agreement reveals a conscious balancing between information that is constituted and arranged in such a way to form the abstract object of security projects and information that is constitutive of personhood and, therein, accorded privacy. In this sense, this partitioning has arguably directed the politics of the PNR agreement away from the definite security practices of monitoring and recording individuals, their movements, their families, travel plans, available contact details (addresses), their political affiliations, to whether or not said individual can be personally identified by authorities who have access to elements of this information. I do not believe this represents so much a retrenchment of security by privacy but rather the expression of a longstanding tendency in the relations between security and liberalism.

If the project of liberalism, as Michel Foucault has claimed, is at once the deployment of apparatuses of security, apparatuses that prefigure liberty and simultaneously in their course of operation 'let things happen', this scheme encounters the private individual of capitalist society in a rather contradictory manner (Foucault, $2007,48)$. In particular, as mentioned earlier, projects of security are deployed to ensure that civil society, the sphere of the 'egoistic individual', remains functional and orderly. Thus the task of security is largely to ensure that market relations are maintained and that 
the relations to production are not disrupted or destroyed. The difficulty that arises here, however, is that much of what ensures that these economic relations retain their order is the individual's freedom to engage in the buying and selling of labour, consumption and commerce. Thus, one has a contradictory stance as the private subject's activity and proclivities must be 'let to happen' and unfold and, at the same-time, the same individual must be policed and monitored to ensure the security of the very economic relations that structure their very appearance as private individuals. Thus privacy and private life are infringed upon by projects of security while these same projects justify their operation through the promotion of the private sphere as a site where the individual remains unfettered and unobstructed in their realization of the liberty of market exchange (Neocleous, 2002, 103). It is arguable that the PNR agreement circumvents this contradiction by rendering abstract life, the anonymous objective features of the social body as permanent objects of registration while positing the real definite lives of the individuals who make up of this social body and, therein, the 'material of registration and surveillance, as that which has the 'right' to exist beyond the remit of projects of security.

Third, the use of privacy in this document arguably serves to sublimate what are direct and repressive relations of rule and coercion into a set of contractual terms. In particular, in practice PNR is used to restrict the mobility of some individuals, to crosscheck (excuse the pun) and add individuals on the DHS 'no fly' list and to track individuals in the hopes of preempting them from compromising national and public security, be this settling in a country 'illegally' or smuggling cocaine. It would be remiss not to state, that there is of course nothing 'random' about which individuals are targeted by PNR. Rather, PNR is a racialized and gendered processes: it is, for instance, far more likely that Muslim men will be subject to PNR targeting rather than white American/European women. However, whether one wishes to participate in this system of relations, let alone challenge it, is non-negotiable.

Yet the inclusion of privacy as an obstacle that security must respect and acknowledge, offers the illusion of personal control. The absence of choice in being recorded, monitored, split into multiple identities stored in separate databases is made palatable by our ability to confront the system. We are given the right to receive our own records: to see ourselves as the authorities see us. If we are delayed or detained we may inquire as to why and, above all, we are assured that our right to privacy ensures that we will be stored in a manner that restores us to anonymity. All of these measures are not only retroactive but pre-determined by the limits of security to begin with: if we receive our own records it is only because they were already recorded; if we are returned to anonymity it is only because we were initially targeted and specified. Yet, further still, not only is privacy then fully inscribed into security, but the success of privacy, its very completion, offers nothing more than a return to the freedoms of private life, which is a return to the freedoms that conditioned and deployed the apparatuses of security in the first instance. 
All of this should be enough to throw-out the concept of privacy or, at the very least, to cease to see security and privacy as counter-veiling forces. Yet I think there are further implications that the advancement of privacy as a right has on social life in capitalist society.

\section{Security, Privacy and Pacification}

We have established the idea that 'privacy' has the effect of disassociating security from the fabrication of private life or, rather, privacy creates the conception that security is distinct and balanced by liberalism. What does any of this have to do with privacy and the further alienation of our collective social power? It is not enough to state that privacy is the means whereby security extends itself into social life and assures us of its own proportionality or reasonableness. Rather, privacy not only fails to challenge capital, as Neocleous has demonstrated $(2002,106)$ but, further still, lends itself to the reification of capitalist social relations and the further separation of the individual to their own social power and objective conditions of life. Privacy not only numbs us to the logics of security and its reasonable agreement to let certain areas of our lives occur seemingly unencumbered by security projects. Rather, it ensures, through the limits privacy sets on our experiences of collective life, the forms of political activity and social engagement that appear possible to us, that in advancing privacy we only further reinforce security and its colonization of "all aspects of human practices and thinking" (Rigakos, 2011, 62).

As Marx noted "labour is, therefore, the objectification of [human] species life," reality is constructed through and mediates upon the social, economic, and biological conditions through which humans contemplate their own objectively constituted existence (Marx, 1975, 76). It follows that species being, as both the object and will of one's practical activity and as the objective reality contained and represented in the products of labour, is estranged by the condition of labour in capitalist society. Thus, in the course of making the worker's product nothing more than the "means to our physical existence" in equal measure species-life itself becomes [merely] a means" as well (Marx, 1975, 77). The estrangement of life and labour from nature and other people force both nature and other people to "appear as objects other than and differentiated from" [the labourer] (Marx, 1975, 78). As such, relations that one confronts independently of one's own particular labour, forces of 'nature' and other individuals appear "as something alien and objective, confronting [individuals] not as their relations to one another but as our subordination to relations which exist independently of [us]" developing merely from the collisions between mutually indifferent individuals (Marx, 1973, 157). To this end, with the advent of capitalist relations, the individual's understanding of themselves as part of a species life dissipates and instead the predominant social bond between individuals is that of "a spontaneous interconnection, [a] material and mental metabolism...independent of 
the knowing and willing individuals [which] presupposes their "reciprocal independence and indifference" (Marx, 1973, 161). Consequently, as the contemplation of social life of life-activity as a shared social product wanes and in its place individuals increasingly find themselves "ruled by abstractions" as objective relations of dependency, the reciprocal relations of production appear separate and autonomous to the individuals who constitute these very relations (Marx, 1973, 164).

My point is not that 'privacy' produces these conditions; the estrangement of individuals from species-life is innate to capitalist production. My point is that privacy serves to further acclimatize us to this reification of species-life as nothing more than the atomized world of the 'individual'. Which is a way of saying that privacy is part and parcel of the process of pacification, a key mechanism in the fabrication of bourgeois order. In particular, it is only in the absence of species-life, when our relations of our social dependence take on the fantastic form of relations between things and relations between people appear as forces alien to us, that the partitioning of social life into private isolated, 'natural' individuals becomes feasible; "liberty is... the right to do everything which does not harm others" it is essentially "the right of the circumscribed individual, withdrawn into him/herself" (Marx, 1975, 42). Thus, the demand for privacy is not merely forever circumscribed by the logics of security but it entrenches the very separations between people presupposed by capitalist social relations that security is used to enforce and maintain. Privacy, then, promises a life apart, a mode of existence separate from others and to this end is presupposed by our appearance as individuals who are autonomous from another and can, therefore, 'choose' to be further detached and apart. Before concluding I think there is an overarching political implication from this relation between privacy, security and capital. This appearance of choice, of course, serves only to further obfuscate the social nature of human existence and our inextricable tie to unequal class, gender and race relations.

By agreeing to live in the form of privacy that is carved out by security projects, we live as individuals who perceive their primary social bond with society to be nothing more than a spontaneous, indifferent and independent set of connections. Any social forces we are confronted by are, by definition, abstractions of the concrete real relations of society. As such, increasingly structural forces such as unemployment, ecological catastrophe, fears about old-age or even general depression or dissatisfaction have the appearance of existing completely suspended from our society and our mode of social (re) production. In this sense, adhering to privacy, as a mode of resistance does not just leave one apart from society but it 'displaces' the social with the 'personal'. In this sense, it is only partially true, as Tocqueville claimed, "as the extent of political society expands, one must expect the sphere of private life to contract" (1968, [1840], 782-3). It may be true that as political society grows, it develops to include new apparatuses to consolidate and legitimate dominant relations of rule (Abrams, 1977, 58); but in capitalist society the growth of political society in any substantive sense (i.e. the common deliberation on life 
in its totality not merely in its forms of abstraction) is utterly antithetical to conditions of accumulation in capitalist society; after-all, the egotistical person "is [in capitalist society] the foundation and presupposition of the political state" (Marx, 1975, 45). However, the opposite holds; as political society shrinks the larger the sphere of 'private social life' looms.

In particular, the less leave we are given collectively to contemplate and organize the objective conditions of social reproduction (education, labour, health-care, old-age) and the more private market relations come to dominate our social experience, the more private life becomes our only mode of contemplation and action. Indeed, although we should not conflate privacy and privatization, the latter historically presupposes the emergence of the former, privacy has increasingly become a force of further commodification. Not solely in terms of direct commodification but in eschewing one's existence as a social being, individuals are increasingly left with no other expression or mode of contemplation outside their own private milieu. As such, when confronted by social, economic and political forces the recourse of the private individual is not to confront these forces as the products of our own objective activity or even as incidents that can be challenged collectively but as personal threats or risks. Thus, each, in the scale of their own atomized sense of reality, manages these personal risks and effects through the only sphere of relations open to the private individual: commodification and correlative security projects. Thus, we purchase security against disease, security against disability, theft, unemployment, old age, etc. as these things crowd into our 'lives apart from society' as nothing more than personal concerns abstracted from the objective concrete relations that determine them. To the extent that human life becomes monadic and takes on the appearance of being assailed by alien forces, the more the demands for protection from these forces is expressed in purchases of private or individual security from these forces; which, in turn, only makes social life all the more atomized and 'apart'. Thus, in the course of drawing on privacy as a means to confront economic and political domination, we are not only acclimatized to the existence of these relations but we are pacified, or at least deterred, from radical, collective forms of political action.

"Security is not just hegemonic, it is hegemony", says Rigakos (2011, 58). Attempts to reveal the tensions and points of incoherency within security projects simply seem to drive the greater refinement of these very projects. In many respects, it is the hegemony of security, its analytical inscrutability that has prompted the turn to pacification both as a concrete historical formation of rule and as an analytical concept, a means to reveal its contingencies, its overlaps, and points of formation (Rigakos, 2011, 61; Neocleous, 2010). The other problem posed by the hegemony of security, implicit to the first problem perhaps, is that in attaining hegemony it has colonized a number of social forms. This means that some relations that appear like sites of possible resistance, such as privacy, in fact form capillary points in the economy of relations behind security. With this problem in mind I have tried to tease out the historical relation of privacy to security 
in capitalist society, so as to demonstrate how the former was, from the outset, entangled with the latter. Security presupposes privacy, decides its scope of power and the facets of social life to which it applies. Furthermore, not only does security condition privacy but also privacy itself, as a mode of life, has the effect of pacifying us to the further penetration of security into social life. Thus, privacy will be in existence for as long as the logics of security remain in play; for, as I outlined earlier in this discussion, it is the private sphere of relations, the sanctity of homo-economicus, that the project of police has long since had as its object. We on 'the Left' would do well to consider these aspects of privacy. As suggested by Tyler Wall's paper in this collection, it is by making appeals to privacy, that drones in the United States have made the transition from battlefield technology to a component of the 'domestic' security apparatus. Following the insights from this paper, it can be argued that challenging drones through privacy will ostensibly experience moderate success. Drones perhaps will only be flown at certain times, in certain areas, and will contravene these rules only when vital security or safety concerns arise. The footage they capture will perhaps even be handled in a manner similar to the PNR data. Yet it is the security apparatus itself, not privacy, that will determine how these limits operate. These limits not only become our measure of freedom and autonomy but also structure our pacification. Thus, in a society that approaches security through the right to privacy, the proliferation of the conduct of war abroad and at home, the organization of human potential into a dehumanizing economic mode of production, will continue apace; insofar as these forces will continue to confront us as happenstance things, filtering in and out of each individual's private, insular existence. To live this pacified mode of life is no less the promise of privacy than it is the guarantee of security.

\section{References}

Abizadeh, Arash, 2013, "Publicity, Privacy, and Religious Tolerance in Hobbes' Leviathan" in Modern Intellectual History, vol. 10, issue 1(forthcoming).

Abrams, Philip, 1988 [1977], "Notes on the Difficulty of Studying the State" in the Journal of Historical Sociology, vol. 1 no. 1 pg. 58-89.

Allen, Anita, 2001, "Is Privacy Now Possible? A Brief History of an Obession" in Social Research, vol. 68 no. 1.

Cavoukian, Ann, 1999, Biometrics and Policing: Comments from a Privacy Perspective, printed in Toronto: Information and Privacy Commission Ontario. 
Colquhoun, Patrick, 1800, [2009], "Treatise on the Police of the Metropolis," in A General Police System: Political Economy and Security in the Age of Enlightenment, printed in Ottawa: Red Quill Books.

Foucault, Michel, 2007, Security, Territory, Population: lecturers at the college de France 1977-1978, printed in New York: Palgrave Macmillan.

Habermas, Jurgen, 1991, The Structural Transformation of the Public Sphere: An Inquiry into a Category of Bourgeois Society, printed in United States: MIT Press.

Hobbes, Thomas, 1968 [1651], Leviathan printed in Great Britain: Pelican Books.

Lyon, David, 2001, Surveillance Society: Monitoring everyday life printed in Great Britain: Open University Press.

Macpherson, C.B, 1973, Democratic Theory: Essays in Retrieval, printed in Oxford: Clarendon Press.

Marx, Karl, 1978 [1843], “On the Jewish Question”, printed in The Marx-Engels Reader ed. Robert Tucker, printed in the United States of America: Norton and Company press.

Marx, Karl, 1978, [1844] "Estranged Labour" printed in The Marx-Engels Reader ed. Robert Tucker, printed in the United States of America: Norton and Company press.

Marx, Karl, 1973, Grundrisse: Foundations of the Critique of Political Economy, printed in Great Britain: Penguin Books.

Meszaros, István, 1970, Marx’s Theory of Alienation, printed in London: Merlin Press.

Mises, Ludwig Von, 1962, Liberalism: A Socio-Economic Exposition, printed in Kansas City: Institute for Humane Studies.

Neocleous, Mark, 2000, The Fabrication of Social Order, printed in England: Pluto Press.

Neocleous, Mark, 2002, "Privacy, Secrecy, Idiocy," in Social Research, vol. 9 no. 2, Spring. 
Neocleous, Mark, 2003, Imagining the State, printed in Great Britain: Open University Press.

Neocleous, Mark, 2007, "Security, Liberty and the Myth of Balance: Towards a Critique of Security," in Contemporary Political Theory vol. 6 131-149.

Nock, Steve, 1993, The Cost of Privacy: Surveillance and Reputation in America. Printed in New York: Aldine de Gruyter.

Ollman, B, 1971, Alienation: Marx's Conception of Man in Capitalist Society, printed in the United States, Cambridge University Press.

O'Hara, Kieron, Shadbolt, Nigel, 2008, The Spy in the Coffee Machine: The End of Privacy printed in England: Oneworld Press.

Rigakos, George, Hadden, Richard, 2001, "Crime, Capitalism and the Risk Society: Towards the Same Olde Modernity?" in Theoretical Criminology, vol. 5 issue. 1.

Rigakos, George, 2011, “To extend the scope of productive labour: pacification as a police project," in Anti-Security, printed in Ottawa: Red Quill Press.

Sennet, Richard, 1976, Fall of Public Man, printed in the United States: Norton and Company.

Smith, Adam, 2009, [1763], "Lectures on Justice, Police, Revenue and Arms," in A General Police System: Political Economy and Security in the Age of Enlightenment, printed in Ottawa: Red Quill Books.

Tocqueville, Alexis de, 1968 [1840], Democracy in America, vol. 2 trans. George Lawrence, printed in New York: Fontana Press.

Whitaker, Reginald, 1999, The End of Privacy: How Total Surveillance is Becoming a Reality, printed in United States: Norton and Company.

\section{Primary Documents}

Council of the European Union, 2011, "Legislative Acts and Other Instruments": Interinstitutional File: 2011/0382 (NLE), printed in Brussels - (PNR Agreement). 